\begin{tabular}{|c|c|c|}
\hline & KEMAS 16 (2) (2020) 175-181 & GKEMAS \\
\hline & Jurnal Kesehatan Masyarakat & 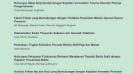 \\
\hline & http://journal.unnes.ac.id/nju/index.php/kemas & 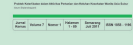 \\
\hline
\end{tabular}

\title{
Energy Intake as the Dominant Factor Associated with Wasting among Children Aged 6-23 Months in Pagedangan, Tangerang District
}

\author{
Aprilya Roza Werdani ${ }^{1 凶}$, Diah Mulyawati Utari ${ }^{2}$ \\ ${ }^{1}$ Nutrition Study Program, Institut Kesehatan Mitra Bunda, Batam, Indonesia \\ ${ }^{2}$ Department of Nutrition, Faculty of Public Health, University of Indonesia, Depok, Indonesia
}

\begin{tabular}{l} 
Article Info \\
\hline Article History: \\
Submitted February 2020 \\
Accepted May 2020 \\
Published November 2020 \\
\hline Keywords: \\
Wasting, food intake, \\
infectious diseases \\
\hline DoI \\
https://doi.org/10.15294/ \\
kemas.v16i2.23427
\end{tabular}

\begin{abstract}
Wasting measured by weight-for-height indices is the malnutrition characterized by a rapid deterioration in nutritional status over a short time. Based on Basic Health Research Data 2018, the proportion of children under two years who were wasting in Indonesia and Banten was $11.7 \%$ dan $13.1 \%$. This study aimed to determine the dominant factor associated with wasting among children aged 6-23 months in Pagedangan, Tangerang District. Cross-sectional designs were used to conduct this study. Data were collected in April-Mei 2019 using anthropometric measurements and questionnaire interviews. Data were analyzed using univariate, chi-square test, and multiple logistic regression. This study showed that the proportion of wasting was $17.0 \%$. Of 153 children aged 6-23 months, $7.8 \%$ were born with low birth weight, $44.4 \%$ had a history of infectious disease, and $32.0 \%$ had a deficit of energy. The proportion of children who had un-met the minimum dietary diversity, the minimum meal frequency, the minimum acceptable diet was $43.1 \%, 15.7 \%$, and $52.9 \%$. The history of infectious disease (OR 2.930, 95\% CI 1.1737.323 ) and inadequate energy intake (OR 5.785, 95\% CI 1.269-26.382) were significantly associated with wasting. Inadequate energy intake was the dominant factor of wasting among children aged 6-23 months in Pagedangan, Tangerang District..
\end{abstract}

\section{Introduction}

Wasting describes an acute malnutrition, usually due to insufficient food intake and / or infectious diseases (Ahmadi et al., 2018). Children are said to be Wasting if the measurement results of the indicator of weight / height or weight / body weight with a z-score $<-2$ SD of the child's growth standard according to WHO (World Health Organization, 2010). In 2017, the prevalence of wasting among toddlers at the global level was $9.9 \%$. WHO estimates that more than two-thirds (69\%) of wasted children live in Asia (UNICEF / WHO / World Bank, 2018). In Indonesia, Basic Health Research Data (Riskesdas) in 2018 shows that the prevalence of wasting in children under five is $10.2 \%$, while in the under two years age group it is higher, namely $11.7 \%$. Banten is one of the provinces with the prevalence of wasting above the national figure, namely $10.5 \%$ in the toddlers group and $13.5 \%$ in the group of under two years old (Kementerian Kesehatan RI, 2018).

Wasting increases the risk of death in children, and is even considered a better predictor of child mortality than stunting (Saaka \& Galaa, 2016). In 2018, the number of deaths of children under five years of age was 5.6 million cases, and $45 \%$ of them were caused by nutritional factors (World Health Organization, 2019). Wasting that occurs early in life can inhibit linear growth or increase the risk of stunting (Richard et al., 2012). In addition, losing is also associated with decreased cognitive abilities (Aguayo, Badgaiyan, \& Dzed, 2017; Venables \& Raine, 2016), decreased 
motor and social skills (Mengistu, Alemu, \& Destaw, 2013) decreased work productivity in adulthood, increased economic burden (Derso, Tariku, Biks, \& Wassie, 2017), as well as decreased immunity which results in an increased risk of infectious diseases (Bourke, Berkley, \& Prendergast, 2016). Wasting also increases the risk of degenerative diseases in adulthood (Matrins et al., 2011).

The high prevalence of Wasting and the many negative impacts it causes, it is necessary to carry out appropriate interventions to overcome Wasting. Therefore, this study aims to determine the factors associated with Wasting in children aged 6-23 months so that it can provide scientific-based information as a basis / reference in making intervention programs to overcome Wasting problems.

Method

This research is a quantitative study with a cross-sectional design, which was conducted in Pagedangan District, Tangerang Regency, Banten Province. The sample of this study was 153 children aged 6-23 months in five selected villages in Pagedangan District, which were selected using multistage random sampling technique. Data were collected through questionnaire interviews and anthropometric measurements (body length and weight).

The dependent variable studied was wasting which was measured using the $\mathrm{BB} /$ $\mathrm{PB}$ indicator. Children are said to be wasting if the $\mathrm{z}$-score $\mathrm{BB} / \mathrm{PB}$ is $<-2$ standard deviation. The independent variables studied were LBW history, infectious disease history, minimum dietary diversity (MDD), minimum meal frequency (MMF), and minimum acceptable diet (MAD), as well as energy, protein, fat and carbohydrate intake. LBW is defined as birth weight less than 2500 grams. Infectious disease history was measured based on the history of acute respiratory infections and / or diarrhea that the child had during the last 2 weeks. MDD is achieved when the child consumes at least 4 of the 7 food groups on the day before data collection. The seven food groups are grains, roots, tubers; nuts; dairy products; meat; egg; vitamin A rich fruits and vegetables; and other fruits and vegetables. MMF is consuming solid, semi-solid, or soft foods (including formula milk for children who are not breastfed) with a minimum frequency or more on the day before data collection, namely as follows: $\geq 2$ times for children aged 6-8 months who are still breastfed; $\geq 3$ times for children 9-23 months who are still breastfed; $\geq 4$ times for children 6-23 months who are not breastfed. MAD is a composite of MDD and MMF. MAD is achieved when MDD and MMF are achieved, and at least 2 times milk consumption for children who are not breastfed. Energy intake and macro nutrients (protein, fat and carbohydrates) were obtained through a 24 -hour food recall.

The data were processed using statistical analysis software. Data analysis used the chisquare test. The significance of statistical tests used $\mathrm{p}$ value $<0.05$. This study also uses the odds ratio or OR as a measure of the association between the independent and dependent variables.

\section{Results and Discussion}

Table 1 shows that $17 \%$ of children $6-23$ months experienced wasting, $11.8 \%$ of them were moderate wasting (malnutrition) and $5.2 \%$ severe wasting (malnutrition). Based on birth weight, $7.8 \%$ of children had a birth weight $<2500$ grams (LBW). The proportion of children aged 6-23 months who did not achieve MDD was $43.1 \%$, did not achieve MMF $15.7 \%$, and did not achieve MAD 52.9\%. The proportion of children with an energy deficit $(<80 \%$ RDA) was $32.0 \%$, a protein deficit $(<100 \%$ RDA) was $52.9 \%$, a fat deficit $(<80 \%$ RDA) was $32.0 \%$, and a carbohydrate deficit was $32.0 \%$. 39.2\%.

Table 2 shows that a history of infectious disease was significantly associated with wasting ( $p$ value $=0.032)$. Children aged 6-23 months who had a history of infectious diseases had a 2.815 times higher risk of wasting than children without a history of infectious diseases (95\% CI 1.165-6,803). In addition, energy intake was also significantly associated with wasting ( $\mathrm{p}$ value $=0.017)$. Children who consumed inadequate energy ( $<80 \%$ RDA) had a 3.067 higher risk of experiencing wasting than children who consumed sufficient energy $(\geq 80 \%$ RDA) (95\% CI 1.293-7,274). Other variables, namely LBW history, MDD, MMF, MAD, and intake of protein, fat, and carbohydrates were not significantly associated with wasting. However, there is a tendency that children who are LBW 
Table 1. Distribution of Children Aged 6-23 Months based on Nutritional Status, Birth Weight, History of Infectious Diseases, Eating Practices, and Nutritional Intake

\begin{tabular}{|c|c|}
\hline Variable & Percentage(\%) \\
\hline $\begin{array}{l}\text { Nutritional status Weight / Body Length } \\
\text { Wasting } \\
\text { Normal }\end{array}$ & $\begin{array}{l}17.0 \\
83.0\end{array}$ \\
\hline $\begin{array}{l}\text { Birth Weight } \\
\text { LBW } \\
\text { Not LBW }\end{array}$ & $\begin{array}{l}7.8 \\
92.2\end{array}$ \\
\hline $\begin{array}{l}\text { Infectious Diseases } \\
\text { Yes } \\
\text { No }\end{array}$ & $\begin{array}{l}44.4 \\
55.6\end{array}$ \\
\hline $\begin{array}{l}\text { Minimum Dietary Diversity (MDD) } \\
\text { Not achieved } \\
\text { Achieved }\end{array}$ & $\begin{array}{l}43.1 \\
56.9\end{array}$ \\
\hline $\begin{array}{l}\text { Minimum Meal Frequency (MMF) } \\
\text { Not achieved } \\
\text { Achieved }\end{array}$ & $\begin{array}{l}15.7 \\
84.3\end{array}$ \\
\hline $\begin{array}{l}\text { Minimum acceptabel diet (MAD) } \\
\text { Not achieved } \\
\text { Achieved }\end{array}$ & $\begin{array}{l}52.9 \\
47.1\end{array}$ \\
\hline $\begin{array}{l}\text { Energy intake } \\
<80 \% \mathrm{RDA} \\
\geq 80 \% \mathrm{AKG}\end{array}$ & $\begin{array}{l}32.0 \\
68.0\end{array}$ \\
\hline $\begin{array}{l}\text { Protein Intake } \\
<100 \% \mathrm{RDA} \\
\geq 100 \% \mathrm{RDA}\end{array}$ & $\begin{array}{l}52.9 \\
47.1\end{array}$ \\
\hline $\begin{array}{l}\text { Fat intake } \\
<80 \% \mathrm{RDA} \\
\geq 80 \% \mathrm{RDA}\end{array}$ & $\begin{array}{l}32.0 \\
68.0\end{array}$ \\
\hline $\begin{array}{l}\text { Carbohydrate intake } \\
<80 \% \text { RDA } \\
\geq 80 \% \text { RDA }\end{array}$ & $\begin{array}{l}39.2 \\
60.8\end{array}$ \\
\hline
\end{tabular}

Source: Primary Data, 2019

and protein intake $<80 \%$ are at greater risk of losing.

Multivariate analysis showed that children who had a history of infection had a 2,930 times higher risk of losing (95\% CI: 1,173-7,323) compared to children who had no history of infectious diseases. Children who experienced a deficit in energy intake had a 5.785 times higher risk of experiencing wasting (95\% CI: 1.269$26,382)$ than children who had no deficit in energy intake.
Wasting is a form of malnutrition that describes acute malnutrition (Adeba, Garoma, Fekadu, \& Garoma, 2014). In this study, it was found that $17.0 \%$ of children aged 6-23 months experienced wasting (11.8\% moderate wasting and $5.2 \%$ severe wasting). A study conducted in North Jakarta in 2017 found that the prevalence of wasting in children aged 6-23 months was smaller than the results of this study, namely 9.2\% (6.8\% moderate wasting and $2.4 \%$ severe wasting).

In this study it was found that infectious diseases and inadequate energy intake were 
Aprilya Roza Werdani \& Diah Mulyawati Utari/ Energy Intake as the Dominant Factor Associated with Wasting

Table 2. Relationship of Birth Weight, Infectious Disease History, Eating Practices, and Nutritional Intake with Wasting

\begin{tabular}{|c|c|c|c|c|c|c|}
\hline \multirow[t]{3}{*}{ Variable } & \multicolumn{4}{|c|}{ Wasting } & \multirow[t]{3}{*}{ OR $(95 \% \mathrm{CI})$} & \multirow[t]{3}{*}{ Pvalue } \\
\hline & \multicolumn{2}{|c|}{ Yes } & \multicolumn{2}{|l|}{ No } & & \\
\hline & $\mathrm{n}$ & $\%$ & $\mathrm{n}$ & $\%$ & & \\
\hline \multicolumn{7}{|l|}{ LBW } \\
\hline Yes & 3 & 25,0 & 9 & 75,0 & \multirow{2}{*}{$\begin{array}{l}1,710 \\
(0,430-6,804)\end{array}$} & \multirow[t]{2}{*}{0,430} \\
\hline To & 23 & 16,3 & 118 & 83,7 & & \\
\hline \multicolumn{7}{|c|}{ Infectious Diseases } \\
\hline Yes & 17 & 25 & 51 & 75 & \multirow{2}{*}{$\begin{array}{l}2,815 \\
(1,165-6,803)\end{array}$} & \multirow[t]{2}{*}{$0,032^{*}$} \\
\hline No & 9 & 10,6 & 76 & 89,4 & & \\
\hline \multicolumn{7}{|c|}{ Minimum Dietary Diversity (MDD) } \\
\hline No & 13 & 19,7 & 53 & 80,3 & \multirow{2}{*}{$\begin{array}{l}1,396 \\
(0,599-3,253)\end{array}$} & \multirow[t]{2}{*}{0,577} \\
\hline Yes & 13 & 14,9 & 74 & 85,1 & & \\
\hline \multicolumn{7}{|c|}{ Minimum Meal Freaquency (MMF) } \\
\hline No & 4 & 16,7 & 20 & 83,3 & \multirow{2}{*}{$\begin{array}{l}0,973 \\
(0,303-3,126)\end{array}$} & \multirow[t]{2}{*}{1,000} \\
\hline Yes & 22 & 17,1 & 107 & 82,9 & & \\
\hline \multicolumn{7}{|c|}{ Minimum Acceptable Diet (MAD) } \\
\hline No & 13 & 16,0 & 68 & 84,0 & \multirow{2}{*}{$\begin{array}{l}0,868 \\
(0,373-2,018)\end{array}$} & \multirow[t]{2}{*}{0,909} \\
\hline Yes & 13 & 18,1 & 59 & 81,9 & & \\
\hline \multicolumn{7}{|c|}{ Energy intake } \\
\hline$<80 \% \mathrm{RDA}$ & 14 & 28,6 & 35 & 71,4 & \multirow{2}{*}{$\begin{array}{l}3,067 \\
(1,293-7,274)\end{array}$} & \multirow[t]{2}{*}{$0,017^{*}$} \\
\hline$\geq 80 \% \mathrm{RDA}$ & 12 & 11,5 & 92 & 88,5 & & \\
\hline \multicolumn{7}{|c|}{ Protein Intake } \\
\hline$<100 \% \mathrm{RDA}$ & 17 & 21,0 & 64 & 79,0 & \multirow{2}{*}{$\begin{array}{l}1,859 \\
(0,772-4,481)\end{array}$} & \multirow[t]{2}{*}{0,238} \\
\hline$\geq 100 \% \mathrm{RDA}$ & 9 & 12,5 & 63 & 87,5 & & \\
\hline \multicolumn{7}{|l|}{ Fat intake } \\
\hline$<80 \% \mathrm{RDA}$ & 9 & 18,4 & 40 & 81,6 & \multirow{2}{*}{$\begin{array}{l}1,151 \\
(0,473-2,805)\end{array}$} & \multirow[t]{2}{*}{0,936} \\
\hline$\geq 80 \% \mathrm{RDA}$ & 17 & 16,3 & 87 & 83,7 & & \\
\hline \multicolumn{7}{|c|}{ Carbohydrate intake } \\
\hline$<80 \% \mathrm{RDA}$ & 13 & 21,7 & 47 & 78,3 & 1,702 & 0,310 \\
\hline$\geq 80 \% \mathrm{RDA}$ & 13 & 14,0 & 80 & 86,0 & $(0,728-3,978)$ & \\
\hline
\end{tabular}

Source: Primary Data, 2019

Table 3. Analysis of Multivariate Logistic Regression for Wasting Risk Factors

\begin{tabular}{lllll}
\hline Variable & $\mathrm{B}$ & $\mathrm{p}$-value & $\mathrm{OR}$ & $95 \% \mathrm{CI}$ \\
\hline Infectious Diseases & 1,075 & 0,021 & 2,930 & $1,173-7,323$ \\
Energy intake & 1,755 & 0,023 & 5,785 & $1,269-26,382$ \\
Fat intake & $-0,406$ & 0,426 & 0,666 & $0,245-1,810$ \\
Carbohydrate intake & $-0,627$ & 0,401 & 0,534 & $0,123-2,310$ \\
\hline
\end{tabular}

Source: Primary Data, 2019 
significantly associated with wasting. The most common infectious diseases in this study were ARI $41.8 \%$, while diarrhea was found to be less, namely $12.4 \%$. The study of Fekadu, Mesfin, Haile, \& Stoecker (2015) shows that children who experience diarrhea have a 2.13 times risk of experiencing wasting. Inflammation that occurs due to infection will increase the need for nutrients and decrease the availability of nutrients which then lead to malnutrition (Walson \& Berkley, 2018). In addition, malnutrition occurs due to chronic inflammation that triggers a decrease in IGF-1 production which can lead to changes in body composition (Bourke, Berkley, \& Prendergast, 2016). Infection triggers an increase in the metabolic rate, increased nutritional needs, decreased appetite, and vomiting (Aryastami et al., 2017). Gastrointestinal infections cause damage to the mucosal barrier and intestinal villi atrophy. This causes malabsorption of nutrients so that the absorption of nutrients is inadequate (Altare, Delbiso, \& Sapir, 2016; Rodríguez, Delbiso, \& Sapir, 2011).

Apart from infectious diseases, nutritional intake is a direct factor affecting nutritional status. Manary, Callagahan, Signh, \& Bried (2016), stated that protein and amino acid intake is needed for growth and infection response. In this study it was found that children who consumed less energy ( $<80 \%$ RDA) had a 3.067 times higher risk of experiencing wasting than children who consumed sufficient energy ( $\geq 80 \%$ RDA). Mwaniki \& Makokha (2013), also found that inadequate energy intake increases the risk of losing. The body needs a constant supply of energy, meaning that the energy expended must be the same as the energy obtained from food. When the amount of ATP is less, the body will activate the catabolic pathways of carbohydrates, fats and proteins. If the intake is inadequate, the body will provide ATP from glycogen reserves through glycogenolysis and from fat reserves through lipolysis, and when needed, the body will produce ATP from cellular proteins. Increased lipolysis causes body fat reserves to decrease so that subcutaneous fat is thinning and there is damage to skin integrity (Gropper \& Smith, 2013).

Low birth weight (LBW) also increases the risk of losing (Habyarimana, Zewotir, \& Ramroop, 2016). LBW is a consequence of inadequate dietary practices during pregnancy which can then cause growth disorders in children (Abubakari \& Jahn, 2016). In addition, LBW is also associated with wasting through the susceptibility pathway to infectious diseases. Children born with low weight are prone to infectious diseases, such as diarrhea, acute respiratory infections (ARI), as well as an increased risk of complications in low birth weight children such as anemia, chronic lung disorders, and decreased appetite (Rahman, Howlader, Masud). , \& Rahman, 2016). However, in this study LBW there was no significant relationship between LBW and wasting.

In 2008, WHO published Infant and Young Child Feeding (IYCF) which is an indicator to assess the feeding practices of infants and children aged 6-23 months. Minimum Dietary Diversity (MDD), Minimum Meal Frequency (MMF), Minimum Acceptable Diet (MAD) are indicators used to assess complementary feeding practices (World Health Organization, 2008). MDD describes the diversity of foods consumed by infants and children. The more types of food consumed, the fulfillment of energy and nutritional needs so as to improve the nutritional status of children (Bandoh \& Kenu, 2017). A study shows that MDD contributes to nutritional adequacy with an OR of 11.1 (Khor, Tan, Tan, Chan \& Amarra, 2016). Previous research has shown that children who do not achieve MDD have a 2.08 times higher risk of losing than children who do (Tariku, Bikis, Woldie, Wassie, Worku, 2017). However, in this study there was no significant relationship between MDD and wasting. This can be explained by the results of the analysis that the food groups that are mostly consumed by children are grains, roots, and tubers (98\%) and fruits and vegetables rich in vitamin A $(73.9 \%)$, while the group's consumption food sources of lower protein. Only $25.5 \%$ of children consumed nuts, $35.3 \%$ of children consumed eggs, $51.6 \%$ of children consumed milk and their processed products, and 54.9\% of children consumed meat, chicken, fish and their processed products. The meat and chicken groups are mostly consumed in processed 
form, such as meatballs, sausages, and nuggets or mixtures and sprinkles of chicken porridge.

Similar to MDD, the MMF indicator also did not statistically have a significant relationship with losing. MMF is defined as the minimum frequency of consumption of solid, semi-solid, or soft foods for children aged 6-23 months, including formula milk for children who are not breastfed (World Health Organization, 2008). The fulfillment of the MMF indicator allows children to meet their energy and nutritional needs so that they can optimize their nutritional status and health. The absence of a significant relationship between MMF and wasting could be due to the inability of this indicator to assess food consumption in quantity, so it is possible that the frequency of consumption has reached the minimum limit but the quantity is inadequate. This is indicated by the results of this study that the average percentage of energy, protein, and carbohydrate adequacy rates was higher in the group of children who did not reach MMF compared to children who achieved MMF.

MAD is a composite indicator between MDD and MMF which represents the balance of quality and quantity of children's diets (Werdani \& Utari, 2019). However, in this study, there was no statistically significant relationship between MAD and wasting. This is because the assessment of food consumption using the MDD and MMF indicators does not take into account the minimum amount consumed (except that very small amounts such as only one or two small bites are not included in the calculation) (World Health Organization, 2008), so that children may eat food varies with the frequency reaches the recommended minimum but in numbers may not be appropriate.

\section{Conclusions}

In this study, we found that the proportion of children aged 6-23 months who experienced wasting was $17 \%, 44.4 \%$ had a history of infectious diseases, and $32 \%$ of children consumed inadequate energy $(<80 \%$ $\mathrm{RDA}$ ), and $52.9 \%$ of children consuming inadequate protein $(<100 \% \mathrm{RDA})$. The results of the analysis show that energy intake is the dominant factor associated with wasting in children aged 6-23 months in Pagedangan
District, Tangerang Regency. Prevention of infectious diseases in children can be done by feeding properly and adopting clean living habits.

\section{References}

Abubakari, A., \& Jahn, A., 2016. Maternal Dietary Patterns and Practices and Birth Weight in Northern Ghana. PLoS ONE, 11(9),pp.1-17.

Adeba, A., Garoma, S., Fekadu, H., \& Garoma, W., 2014. Prevalence's of Wasting and its Associated Factors of Children among Months Age in Guto Gida District, Oromia Regional State, Ethiopia. Journal of Food Processing \& Technology, 5(1).

Aguayo, V.M., Badgaiyan, N., \& Dzed, L., 2017. Determinants of Child Wasting in Bhutan. Insights from Nationally Representative Data. Public Health Nutrition, 20(2),pp.315324.

Ahmadi, D., Amarnani, E., Sen, A., Ebadi, N., Cortbaoui, P., \& Melgar-Quiñonez, H., 2018. Determinants of Child Anthropometric Indicators in Ethiopia. BMC Public Health, 18,pp.626.

Altare, C., Delbiso, T.D., \& Guha-Sapir, D., 2016. Child Wasting in Emergency Pockets: A Meta-analysis of Small-Scale Surveys from Ethiopia. International Journal of Environmental Research and Public Health, 13,pp.178.

Aryastami, N.K., Shankar, A., Kusumawardani, N., Besral, B., Jahari, A.B., \& Achadi, E., 2017. Low Birth Weight was the Most Dominant Predictor Associated with Stunting Among Children Aged 12-23 Months in Indonesia. BMC Nutrition, 3(1),pp.1-6.

Bandoh, D. A., \& Kenu, E., 2017. Dietary Diversity and Nutritional Adequacy of Under-fives in a Fishing Community in the Central Region of Ghana. BMC Nutrition, 3(2).

Bourke, C.D., Berkley, J.A., \& Prendergast, A.J., 2016. Immune Dysfunction as a Cause and Consequence of Malnutrition. Trends in Immunology, 37(6),pp.386-398.

Derso, T., Tariku, A., Biks, G.A., \& Wassie, M.M., 2017. Stunting, Wasting and Associated Factors Among Children Aged 6-24 Months in Dabat Health and Demographic Surveillance System Site: A Community Based Cross-sectional Study in Ethiopia. BMC Pediatrics, 17(96).

Fekadu, Y., Mesfin, A., Haile, D., \& Stoecker, B.J., 2015. Factors Associated with Nutritional Status of Infants and Young Children in Somali Region, Ethiopia: A Cross- sectional 
Study Global Health. BMC Public Health, $15, \mathrm{pp} .846$.

Gropper, S.S., \& Smith, J.L., 2013. Advanced Nutrition and Human Metabolism. In Advanced Nutrion in Human (Sixth Edit). Wadsworth, Cengage Learning.

Habyarimana, F., Zewotir, T., \& Ramroop, S., 2016. Key Determinants of Malnutrition of Children Under Five Years of Age in Rwanda: Simultaneous Measurement of Three Anthropometric Indices. African Population Studies, 30(2),pp.2328-2340.

Kementerian Kesehatan RI., 2018. Laporan Nasional Riskesdas 2018. Kementerian Kesehatan RI.

Khor, G.L., Tan, S.Y., Tan, K.L., Chan, P.S., \& Amarra, M.S.V., 2016. Compliance with Who IYCF Indicators and Dietary Intake Adequacy in a Sample of Malaysian Infants Aged 6-23 Months. Nutrients, 8,pp.778.

Manary, M., Callaghan, M., Singh, L., \& Briend, A., 2016. Protein Quality and Growth in Malnourished Children. Food and Nutrition Bulletin, 37(Supplement 1),pp.S29-S36.

Matrins, V.J.B., Toledo-Florêncio, T.M.M., Grillo, L.P., Franco, M.do. C.P., Martins, P.A., Clemente, A.P.G., Santos, C.D.L., Vieria, M.de.F.A., \& Sawaya, A.L., 2011. Long-lasting Effects of Undernutrition. International Journal of Environmental Research and Public Health, 8,pp.1817-1846.

Mengistu, K., Almu, K., \& Destaw, B., 2013. Prevalence of Malnutrition and Associated Factors Among Children Aged 6-59 Months at Hidabu Abote District, North Shewa, Oromia Regional State. Journal of Nutritional Disorders \& Therapy. 2013.

Mwaniki, E.W., \& Makokha, A.N., 2013. Nutrition Status and Associated Factors Among Children in Public Primary Schools in Dagoretti, Nairobi, Kenya Nairobi, Kenya. African Health Sciences, 13(1),pp.39-46.

Rahman, M.S., Howlader, T., Masud, M.S., \& Rahman, M.L., 2016. Association of Lowbirth Weight with Malnutrition in Children Under Five Years in Bangladesh: Do Mother's Education, Socio-economic Status, and Birth Interval Matter? PLoS ONE, 11(6),pp.1-16.

Richard, S.A., Black, R.E., Gilman, R.H., Guerrant,
R.L., Kang, G., Rasmussen, Z.A., Sack, R.B., Valentiner-branth, P., \& Lanata, C.F., 2012. Wasting Is Associated with Stunting in Early Childhood. The Journal of Nutrition, 142,pp.1291-1296.

Rodríguez, L., Cervantes, E., \& Ortiz, R., 2011. Malnutrition and Gastrointestinal and Respiratory Infections in Children: A Public Health Problem. International Journal of Environmental Research and Public Health, 8,pp.1174-1205.

Saaka, M., \& Galaa, S.Z., 2016. Relationships between Wasting and Stunting and Their Concurrent Occurrence in Ghanaian Preschool Children. Journal of Nutrition and Metabolism, 11.

Tariku, A., Bikis, G.A., Woldie, H., Wassie, M.M., \& Worku, A.G., 2017. Child Wasting is a Severe Public Health Problem in the Predominantly Rural Population of Ethiopia: A Community Based Cross-sectional Study. Archives of Public Health, 75,pp.26.

UNICEF/WHO/World Bank., 2018. Global Overview Child Malnutrition Regional Trends. In UNICEF/WHO/World Bank.

Venables, P.H., \& Raine, A., 2016. The Impact of Malnutrition on Intelligence at 3 and 11 Years of Age: The Mediating Role of Temperament. Developmental Psychology, 52(2),pp.205220.

Walson, J.L., \& Berkley, J.A., 2018. The Impact of Malnutrition on Childhood Infections. Current Opinion in Infectious Diseases, 31(3),pp.231-236.

Werdani, A.R., \& Utari, D.M., 2019. Association of Infant and Young Child Feeding Practices with Linear Growth of Children under 24 Months in Asia and Africa. Pakistan Journal of Nutrition, 18(7),pp.665-670.

World Health Organization., 2008. Indicators for Assessing Infant and Young Child Feeding Practices.

World Health Organization., 2010. Nutrition Landscape Information System (NLIS) Country Profil Indicators: Interpretation Guide. WHO Press.

World Health Organization., 2019. Children: Reducing Mortality. 